\title{
Some discussions between Confucianism and Catholicism in Vietnamese history
}

\author{
Dong Tai Nguyen
}

DOI: 10.18355/XL.2022.15.01.14

\begin{abstract}
When Catholicism was introduced into Vietnam, there was also a tendency toward differentiation and even confrontation with Vietnamese culture, including Vietnamese Confucianism. This article focuses on the discussion between Confucianism and Catholicism from the Ideological perspective, on the most basic concepts about belief related to God, the most popular religious activity, which is worshipping activities, and the social-moral code encompassing the two most basic aspects during that time: loyalty and piety.
\end{abstract}

Key words: Confucianism, Catholicism, discussion, God, worship, loyalty, piety

\section{Introduction}

During the period of absolute monarchy in Vietnam, differences, collisions, and even contradictions among ideologies and religions were not uncommon. Although the general trend was The Three-Religion Concourse, the attacks of Confucianism on Buddhism and Taoism sometimes went beyond the academic field, directly impacting the Court's policies and changing the face of both Buddhism and Taoism. However, these conflicts were far less severe than those between Confucianism and Catholicism in the history of Vietnam.

There have been some works indirectly discussing the relationship between Catholicism and Confucianism, focusing on some well-known missionaries, such as Barbara Widenor Maggs' research about Alexandre de Rhodes (Vietnamese name is Dac Lo) (Maggs, 2000), or George E. Dutton's book about Felippe do Rosario (Vietnamese name is Philiphê Bỉnh) (Dutton, 2017), and about the Portuguese missionaries (Fernandes \& Assunção, 2017) and later the French missionaries in Vietnam. The role and credit of Catholicism in Vietnam were examined in their multiple aspects, above all in the aspect of education, i.e., the formation of Vietnamese script and schools that were maintained by the Catholic Church (Osborne, 1969).

When discussing the relationship between Christianity and Confucianism, some papers focus on the relationships between Christianity and the ideologies and religions in Vietnam, usually called by the name "The Three-Religion Concourse," which are Confucianism, Buddhism, and Taoism. When studied about Caodaism, Janet Alison Hoskins discovered the special relationship among the beliefs in this new polytheism, in which Jesus was put into the God system. However, the position was junior compared to that of the old Gods: "Jesus is part of this pantheon, but in a relatively junior status, placed three levels below Buddha, Lao Tzu, and Confucius" (Hoskins, 2014: S302). When researching the reasons why Hue Court advocated against Catholicism, the authors stated multiple reasons, including not only the French invasion but also the association of the colonial and the missionaries that had offended the deepest values of Vietnam, of which the symbols are incense vases and ancestral altars in families (McLeod, 1991).

Similar to Buddhism, Confucianism, and Taoism, Catholicism originated from the East; however, as time went by, this religion moved from the Middle East and North Africa to Europe and became a Western religion. Therefore, the collisions between the two beliefs, cultures, and East-West systems when Catholicism was introduced into Vietnam were unavoidable. The study, intense scrutiny, criticism, and attack by some Catholic scholars of Buddhism, Confucianism, Taoism, and even Vietnamese folk religion were not uncommon in history, especially during the $19^{\text {th }}$ century. 
However, the attitude of the people who followed Buddhism and Taoism in Vietnam at the time was fairly conciliative and lenient. In contrast, the reactions of Confucian scholars were much stronger and more dramatic. This article will focus on the dialogues about the basic reasoning issues of these two ideologies/religions.

In modern East Asia, the invasions and colonizations activities were typically linked to missionary activities. "It means, anywhere in the Afro-Asian world, missionary works were developed thanks to colonization, military occupation, territorial concessions, and political repression" (Cao, 2003: 9). However, not all missionary activities were attached to invasions or colonizations. Before colonialism came into Vietnam, there had been many conflicts between Confucianism and Catholicism. Before the French people and French colonials invaded Vietnam, the priests were mainly Portuguese and Spanish. Even after France invaded Vietnam, colonialism and Catholicism could not be homogenized. According to Cao Huy Thuan, the problem can be viewed based on the conflict between religious benefits and colonial benefits (Cao, 2003: 24). History offers us a fitting story that can be used as evidence for this. Famous Catholic priest Dang Duc Tuan (1806 - 1874), when arrested by the Court's military and escorted to capital city Hue to be questioned about colluding Catholicism with French enemies, explained the differences between colonialism and religion, enemy and faith. He narrated in the book A Narrative of Events in the Nam Country (Narrating about Catholicism in Vietnam):

"If the invaders came from the Romanian Catholic Church

Then I would admit that Catholicism is the enemy that destroys our country

But it is not the truth

It was France who started the war

I do not know this (French) enemy

But maybe they started the war to seek benefits" (Vu - Nguyen, 2003: 218).

He explained that it was France that invaded Vietnam instead of Rome, and the country's disaster was not related to Catholicism; therefore, when advised to renounce the religion, he was determined not to renounce it, believing that religion and enemy are different:

"I will not renounce the teaching/religion because of the time tendency

(it is rather) because of Christianity but not the French

The Court as the parents can punish me

It is not easy for me to feign

Everything is self evidently true" (Vu - Nguyen, 2003: 219).

Along with the explanation and six reports (Nguyen, 2017) sent to King Tu Duc before and after that, the love for religion and the country that radiated from the Catholic priest Dang Duc Tuan moved the Court. Not only was he released from all charges but also appointed as Phan Thanh Gian and Lam Duy Hiep's assistant. He was then sent to Gia Dinh on behalf of the Court to negotiate with France in 1862. A great modern Confucian scholar and thinker, Phan Boi Chau, also acknowledged the need for the nation to be open to diversity and leniency. When hearing about the passing of Bishop Allys Ly, Phan Boi Chau wrote a funeral oration that included these lines:

"All those who embrace the spirit of patriotism, regardless of skin color, are the Vietnamese

A half of century of ringing the God's bell, assisting the deaf and mute to communicate, changing evil/ merciless dreams into good ones

All believers, from the North to the South, from far and near, all hope the nation will become joyful and happy" (Phan, 1990: 341-342).

For three centuries before the French colonial invasion in Vietnam (if counting from 1533 according to 欽定越史通鑑綱目 [The Imperially Ordered Annotated Text Completely Reflecting the History of Viet], there were contradictions and conflicts XLinguae, Volume 15 Issue 1, January 2022, ISSN 1337-8384, eISSN 2453-711X 
between Confucianism and Catholicism, between missionaries and Confucian scholars, between government officials and parishioners. One should note that right from the middle of the $17^{\text {th }}$ century, Vietnamese religious people were killed by the Court. Catechist Andrêa was the first martyr of the South congregation on July $26^{\text {th }}$, 1677. He was baptized and instructed by Alexandre de Rhodes (Nguyen, 2009: 165168). Nineteen years later, according to Vietnamese history books, the policy of forbidding religions appeared for the first time: "Before, there was a Westerner called Hoa Lang Di, who came into our country and brought along Catholic superstition to trick and entice the people, who were cloddish, superficial, and mostly trusting religions; they set up pulpits and listened to preaching, and that passionate delusion was getting bigger as time went by. There was an order issued to evict that missionary, but the small-minded people into whom that custom deeply penetrated have not changed thus far" (Nguyen Dynasty's Bureau of National Historiography. 1998: 300-301). The Le dynasty and Nguyen dynasty kings considered Catholicism as a heresy that contradicts Confucianism, which is regarded as righteousness.

Several research projects have mentioned the conflicts between Confucianism and Catholicism in Vietnam from various perspectives, using Vietnamese history books, Catholic history books, the Church history, direct articles about this matter ${ }^{1}$, etc. However, this research has not generated sufficient results. In addition to the aspects of belief, culture, and politics, the conflicts between Confucianism and Catholicism on the level of thought are quite remarkable and important.

\section{The matter of Divinity}

\subsection{Divinity as Lord of Heaven}

Imperial edict by Tu Duc directly criticizes the most basic and sacred foundation of Catholicism, which is the Lord of Heaven: "They said that the Lord of Heaven is the Supreme Emperor, and the Supreme Emperor is the Lord of Heaven, who creates heaven, earth, and lives. However, they also said that God is not heaven, not earth, not a reason, not Dao (道), not material energy (氣), not inherent quality (性), not a human, not an object, not a ghost (鬼), not a Spirit (神); that is the clue of everything, but he himself begins from nowhere... when compared to Lao Tzu's statement: 'Namelessness (無名) is the start of everything, Taoism yields one, one yields two,' it is obvious that Catholicism's theory is even more primitively twisted, they only knew how to use God to hide the traces of Catholicism, to decorate their mistake about wrongfully worshipping without considering the origin" (Tu, 1858: 44).

When it comes to key theories of a given religion, Catholicism's foundations are the immortal soul theory, heaven - hell theory, etc. Even Gia Long himself, who received massive support from Catholicism and had particular sympathy with the priests, ${ }^{2}$ still expressed a critical attitude towards this religion numerous times. Townsman's regulation (鄉黨條例), published in 1804 during the reign of King Gia Long stated: "Again, Catholicism is a foreign religion, which was introduced into our country, that fabricates the teaching of heaven and hell to make stupid men behave like crazy and get infected by it without knowing it" (Main parts of chronicles of the Great Nam, 1963a: 168).

In 1832, King Minh Mệnh gave an imperial order that: "Catholicism has been propagated by Western people for quite a while now, and most of the ignorant were

\footnotetext{
${ }^{1}$ This was mentioned typically in the articles of the authors Nguyen Hong Duong, Nguyen Quang Hung, Do Quang Hung and others.

${ }^{2}$ When Ba Da Loc (Pigneau de Behaine) died, Nguyen Anh deeply mourned his death, he built a mausoleum and expressed his deep feelings. Dang, D. T wrote: "going to Gia Dinh for the burial/ Setting up the mausoleum to highlight the high merits / The Eastern palace is full of tears" (see: Vu - Nguyen, 2003: 210-222).
} 
deceived without having regrets. Try thinking: the heaven theory, in short, is just unreal and without any evidence. In addition, not respecting divinity and not worshipping ancestors are heavily against righteous religion. They even set up their own pulpits, gather people, luring and lewding women in an extremely cruel fashion. These immoralities and corruptions, which are still plentiful, have violated the law" (Main parts of chronicles of the Great Nam, 1963b: 236).

In the Conference of Distinguished Teachers of Four Religions, ${ }^{3}$ Confucian scholars and the Western priests had a different conception about "God" (Conference of Distinguished Teachers of Four Religions, 1996: 38-39). Confucianism use I Ching (The Book of Change) as the basis for the conception about God: "superior and inferior principles of nature is called Shen, mysterious" (Quoted from Nguyen, 1992: 453), while the Western priests think that God has to be Divine (Đấng thiêng liêng phép tắc); Therefore, when God is perceived in a yin-yang, lifeless understanding, he cannot protect human, nor can he protect a country and its people.

\subsection{The matter of ontology}

Attached to the issue that God is the ultimate Lord of Heaven is the ontological issue, regardless of whether it is natural ontology or human ontology. Catholicism opposes Confucian ontological conceptions, which is expressed in the book Conference of Distinguished Teachers of Four Religions. It is a fictional book with the background set in the late $18^{\text {th }}$ century, inside the Viceroy Tinh Do Trinh Sam's estate (靖都王鄭 森). The book presents the discussion among the representatives of the four ideologies and religions, which are Confucianism, Taoism, Buddhism, and Catholicism: "At the time, there was a great mandarin, who was Tinh Do Vương Lord's uncle without a religion, whose mother was from Canh Vien, Hai Duong, with a high social position who usually advised him to choose a religion to follow. However, the obscure mandarin did not know which religion was righteous. While observing the Lordhonoring monks, Buddhist nuns, as well as thinking high of Buddhist enchanters, he wanted to follow the Lord's step, hoping it would be easier. Yet, since his mother emphasized the importance of religion and he was a pious son, he wanted to please his mother's desire. One day the Mandarin demanded that people of different religions come to his estate and tell him about their doctrines so that he might understand each of them. One Confucian scholar, one Lao Tzu scholar, one Buddhist scholar, and two priests were brought to the estate" (Conference of Distinguished Teachers of Four Religions, 1996: 20). The author could be a missionary who mainly employed askand-answer type of reasoning to assert Catholic theories when confronting the three traditional religions' theoretical points.

In this document, Confucian scholars always asserted that the three religions are righteous religions, considering Catholicism as superstitious and deceitful: "Not only

\footnotetext{
${ }^{3}$ The reference here is to the book: Conference of Distinguished Teachers of Four Religions. Texts are in Vietnamese, Nom, and Chinese languages, Documents for internal circulation only. This book allows us to look at not so distant past. Although the Conference of Distinguished Teachers of Four Religions was published after 1858, due to its importance and summary of previous basic conceptions, we use it in our analysis as an evidence in this paper. Additionally, books related to the propagation of Christianity were introduced to Vietnam by missionaries. Typically, this was the case of Matteo Ricci's The True Meaning of the Lord of Heaven (1603). His book was introduced in Vietnam in 1630 (according to Pham Huy Thong). This also applies to Alexandre de Rhodes' "Catechism divided into Eight Days]The 8-day Sermons, " published in 1651. The Conference of Distinguished Teachers of Four Religions is not only an "elucidating" book, but also an "apologetic" book to defend the authenticity and rationality of beliefs and practices of a religion or ideology. In Christianity, this style of writing not only explains and elucidates the doctrines of the religion (vintage) but also fights against doctrines and practices that may threaten the Christian faith. (See: Tran, 2020: 72).
}

XLinguae, Volume 15 Issue 1, January 2022, ISSN 1337-8384, eISSN 2453-711X 
our country but also 18 other nations in the East, all the Kings and the noble, who are following/respecting the past and looking for the future, all respect the three religions and make them official religions. As a foreign Hoa Lang religion, it is a heresy without any truth and full of absurd lies; therefore we do discuss it" (Conference of Distinguished Teachers of Four Religions, 1996: 21). To object to Confucian's opinion, Western priests alleged that the Three religions are not "Since ancient times" (從古以來), because Fuxi (伏羲), Shennong (神農), Huangdi (黃帝), Emperor Yao ( 堯) and Shun (舜) etc., had existed before the three religions. In addition, the three religions were supposedly not "our own three religions," because "they all originated from other countries" (Conference of Distinguished Teachers of Four Religions, 1996: 22). Therefore, there should be no xenophobic attitude towards Catholicism.

Among the three significant problems, the first one mentioned by the Conference of Distinguished Teachers of Four Religions pertained to human ontology: "So what is the First Philosophy, where is the ontology of human being?" (Conference of Distinguished Teachers of Four Religions, 1996: 25). Following this question, Confucian scholars published a conception about “Taiji” (太極). The Western priests opposed Taiji and Qi Ontology (氣本論): “Therefore, I do not appreciate that Confucianism decided to take Taiji as the origin of everything, due to the fact that Taiji is the air, it is absolutely not the divine that can create everything" (Conference of Distinguished Teachers of Four Religions, 1996: 27). The Western priests' rejection of this approach stemmed from the fact that they could not accept the naturalistic explanation of Confucian scholars for the two significant questions: what makes infinity into yin and yang (ontologism) and what makes Taiji move and evolve (cosmology). The Western priests explained ontological problem based on the conception in the Bible: bring everything back to God (Conference of Distinguished Teachers of Four Religions, 1996: 30-31). Some Confucian and Eastern concepts can be recognized here, such as "blessing," "virtue," etc., being used to explain God.

The Western priests also opposed the conception of Li Qi (理氣) and Yin Yang (陰陽 ) doctrine. They believe that the sky and earth are the houses instead of the host and that the host is more important than the house itself (Conference of Distinguished Teachers of Four Religions, 1996: 32). Based on such reasoning, the Western priests thought that Supreme Emperor (上帝) in Confucianism ((The Kongzi Jiayu 孔子家語 )) is the God of the Bible. The title post Preface (序) in Essential Teachings of the Holy Religion (聖教要理) (Catechism, 1997) opposed Buddhism, Taoism, Confucianism, as well as Li Qi ontology (理氣本體論): “The first Lord of Heaven, Earth, God, and Man is the only god, majestic and difficult to name. For by him all things were created, there is nothing to predict"4 (Catechism, 1997: 360)

\subsection{The matter of Confucius}

Some missionaries criticized Confucianism mainly from the religious perspective of this doctrine. They did not consider Confucius as a saint and did not acknowledge traditional worshiping rituals. Not criticizing moral conceptions or political and social thoughts of Confucianism, they rejected the sacredness of Confucius. History of the Kingdom of Tonkin (Lịch sủ vuong quốc Đàng Ngoài) of Alexandre de Rhodes criticized the fact that people called Confucius a "saint":

"The first and best-known religion is Confucianism. The founder of this religion was a Chinese named Confucius, who lived in China. According to historical records, he lived at the same time as Aristotle in Greece, that is,

\footnotetext{
4 “首尊天地神人之主。一元真宰, 浩蕩難名。萬有資生, 淵微莫測。惟因物欲相循。遂 致秉彝子眜。加以空門禪釋。雜以黃老僊巫。儒者尚文。侈談理氣。愚夫易惑, 罔識本 原。” (Preface in Chinese) å(See: Catechism, 1997: 360)
} 
about three hundred years before the birth of Christ. People from the North regard him as a saint, but it is absurd and contrary, as I once convinced them. Because, in my opinion, if he is to be called a saint, then he must know that there is a God who created heaven and earth, if he does not know it, how could he be a saint; he does not know (that God) was the source and cause of all holiness, who communicates only to rational beings through their knowing and loving the great God. If he realizes that, since he claims to be a doctor and a teacher, he must teach the knowledge necessary for salvation. He does not teach clearly in his scriptures; he does not mention God. God is the principle of everything; how can he be called a saint?" (Rhodes, 1994: 39-40).

Therefore, Alexandre de Rhodes considered Confucianism wicked. In Cathechismvs in octo dies diuisus (Phép giảng tám ngày), he wrote: "But Confucius did not do that. Therefore, he is not wise, nor is he a saint" (Rhodes, 1993: 112-113).

We should remember here that not all missionaries criticized Confucianism or denied everything about Confucianism; instead, they denied the piety of this doctrine or its impact on people's beliefs. In 1615, Buzomi rated highly Confucianism's role in Vietnamese society: "Thanks to Confucianism, Vietnamese society and family have had high organization, Vietnamese people have had the admirable traits and customs, which helped a lot in missionary work" (Quoted from Nguyen, 1959: 57). The matter of worshipping in general and worshipping Confucius specifically as a means of commemoration and appreciation is acceptable; however, it can not be a means to ask for protection from the saints and gods because Confucius is not a saint. He is a human.

"The Western priests said: Confucian scholars admire Confucius as an erudite Superior, who had laid out the books that descend the righteous and fair justifications down to other people. The fact that people prayed with him for being smart and successful in the court exams but got nothing means that this miracle power belongs only to one Creator (God). And Confucious was an ordinary man and cannot have that miraculous power" (Conference of Distinguished Teachers of Four Religions, 1996: 43).

\section{The matter of worshipping}

\subsection{Worshipping gods}

Similar to the case of Confucius, Catholicism also denied Vietnamese people's divine system, including gods, with the king's royal honor-conferring diploma. When answering the question "we worship the Gods and Heroes who have earned respected position and fame in their life, earned the royal diplomas as First and Intermediate class deities, along with the Royal Highest and Great Saint; why does the religion prohibit us from worshipping and offering sacrifices?", the Western priests believed that these people did not know about the Lord of Heaven. If someone is against the Lord, that person cannot be a deity: "Are those people truly a deity? That is a totally evil spirit and the devil (妖精厲鬼)” (Conference of Distinguished Teachers of Four Religions, 1996: 58-59). Alexandre de Rhodes criticized the atheistic conception of Confucianism. "From the perspective of theology, even when we set aside the matter of the Creator and the denial of human's immortal spirits, his doctrine has 'gone to an atheistic place, opened the door for all bad habits, leaving a tarnished image, an outside appearance of benevolence"" (Nguyen, 2009: 52).

We should add that the Nguyen dynasty truly valued offering sacrifices. The unspoken rule was that making sacrificial offerings to Heaven and praying to stars were the tasks for Confucian mandarins only. If Buddhist and Catholic mandarins had done the same, they would have been accused of "disrespecting gods" and severely punished (Nguyen Dynasty's Cabinet, 1993: 373). During the reign of the Nguyen

XLinguae, Volume 15 Issue 1, January 2022, ISSN 1337-8384, eISSN 2453-711X 
dynasty, the esplanades were used for sacrifices, imperial temples, royal tombs, temples of literature, etc., and considered sacred land. The mandarins who executed the activities of offering sacrifices were also sacred. Going against the ceremony would have been severely punished, as pertained to these activities of offering sacrifices. The strict rules of the Court about offering sacrifices contained the harmony of "Heaven - Human Induction" (天人感應), “Emotional sense of Heaven and Earth” (天人相感) from the Han Confucianism. They were also full of religious traits. Therefore, neither Buddhism, Taoism, nor folk belief could officially participate in these activities.

\subsection{Worshipping ancestors}

At the beginning of the 18th century, Pope Clément XI declared that worshipping ancestors went against the tenets of Catholic doctrine. ${ }^{5}$ The 24 clauses of Worship Prudence (Nhân đức thờ phuơng) (besides faith, hope, charity, etc.) were used as the 24 criteria to consider if a religious person committed a sin. The first clause is "Did they libel the Holy God?". Libeling the Holy God was a serious sin because this was the core, the root, and the beginning of all beginnings, the most basic foundation of Catholicism. In addition, there were clauses that directly related to other ideologies and religions in Vietnam at the time: referring to Buddhism, Taoism, the belief of worshipping ancestors, etc. Most importantly, there were multiple clauses that referred to the activity of worshipping ancestors. The clauses further criticized the book Family Rites (家禮) (Gendreau, 2004: 83-85). The Holy See clearly stated (Gendreau, 2004: 253-262) that those activities could not be done when there was someone passing away and opposed traditional customs, including ones directly related to the belief of worshipping ancestors (Gendreau, 2004: 256-259) King Tu Duc articulated the following critical remark: "They want people to stop worshipping ancestors, parents, and Confucian deities, saying that the Lord of Heaven is the foundation of humanity, of all things, of gods, and people should focus on paying homage to the Lord of Heaven. Then they made a big mistake" (Tu, 1858: 46).

\section{The matter of piety and loyalty}

\subsection{Piety}

Loyalty and piety are considered the two most important norms for Confucian scholars, as well as for Vietnamese during the absolute monarchy. Nguyen Trai, a great thinker of Vietnam in the $15^{\text {th }}$ century, wrote: "Only Loyalty and Piety are forever unchanged (“盃固沒峼忠免孝, 砙庄缺染庄顛” (Nguyen, 1976: 24). Mencius himself also had a famous quote when criticizing Yang Zhu (杨朱) and Mozi (墨翟): "Being without a father and without a ruler is to be a wild animal"6 (Quoted from Ly, 2010: 697-698). In the meantime, Confucian scholars used the said thoughts to criticize Catholicism.

Tay Son dynasty thought of Catholicism as a religion without a king, a father, and respect for gods" (Quoted from Nguyen, 2008: 202). In fact, the theory of being dutiful and respectful to parents in Catholicism has many points that are close to Confucian piety. In God's Ten commandments, the first three commandments are directly related to the Lord of Heaven, and the fourth is about being respectful to parents. Vietnamese Catholicism in the $17^{\text {th }}$ and $18^{\text {th }}$ centuries also emphasized this, asserting their piety with seven specific rules: "The fourth commandment teaches children to be dutiful and respectful to their parents." (Conference of Distinguished Teachers of Four Religions, 1996: 72).

\footnotetext{
${ }^{5}$ On the issue of the relationship between ancestor worship and mission and the related disputes, see: (Vu, 2018).

6 “杨氏为我，是无君也；墨氏兼爱，是无父也。无父无君，是禽兽也。”《孟子·滕文公下》
} 
Three father (三父) theory, according to Mateo Ricci, claims that a mortal has three fathers in the universe: one is God, the other is the monarch, and the third is the father in the family (凡人在宇内有三父: 一谓天主, 二谓国君, 三谓家君也). In Cathechismvs in octo dies diuisus, Alenxandre de Rhodes wrote: "Now we need to have three superiors, called the three fathers whom we need to worship in a correct manner respectively. The lower superior is the parents who gave birth to us; the intermediate superior is the kings and lords that rule the nation; the upper superior is the Lord of the sky and earth, the Lord that is above all. Only with these three superiors can we be alive and live to the fullest. Only by having parents who gave birth to us can we have a body. Kings and lords can also be called 'father' who takes care of the people. Without kings and lords, a nation cannot be peaceful... God is above all; it is important that there are both rewards and punishment" (Rhode, 1993:17-24). Alexandre de Rhodes inherited the three moral bonds to complement the conception of the Lord of Heaven. In the history of Vietnamese thought, the use of concepts, structures, conceptions from other doctrines to develop our own doctrine is not uncommon. Right from the beginning of the $17^{\text {th }}$ century, some parishioners used sophisticated, respected words and names in Buddhism and Confucianism to call the Lord of Heaven: "The Holiest of Holy" (Chí thánh), "Great Compassion” (Đại từ bi):

"The Holiest of Holy and the Great Compassion, please bless us with the ways to save the barbarians' small country, to help all the noble and the low of the Annam enjoy the sacred path and abandon all other wrong paths, get rid of sinking/suffering and enjoy blessings. The servants of (your) religion bow our head sincerely with this letter" (Nguyen, 2001: 191).

Dang Duc Tuan repeated Three father theory, in which there was an assertion that "Religion teaches people to worship the king" and justification for not opposing loyalty (as well as associated it with piety from Confucianism's opinion).

"The religion teaches to worship the sacred God

Who created heaven and earth and rules over life and death

Whenever people have spirituality

Keeping the righteous path of eternal life in heaven

The religion teaches to worship the king under heaven

Because the king rules the people on behalf of the gods

The religion teaches filial piety and reverence

To treat parents with care and gratitude" (Vu- Nguyen, 2003: 219).

God, King, Parents are the three fathers with different rights and claims on loyalty. Vietnamese Catholicism seriously appreciated the piety towards parents but opposed the idea of worshipping them along with religious ceremonies. A Catholic stele wrote: The managing/ruling bishop, priest of Quynh Coi, Nguyen Huu Nguyen, please give me permission to have one (...) engraved on the stele for memorization. From the year of the Tiger to the year of the Tiger, about 30 years, thinking about the merits of 9 months of pregnancy, three months of breastfeeding, the nourishing labor is like the wide sea, the gratitude is like a high mountain touching the heavens and the earth. (Vuong, 2000: 195)

\subsection{Loyalty}

To protect itself, Catholicism asserted that its tenets also teach about loyalty to the leader. "Confucian scholars asked: Does your religion tell people to worship Kings and Lords? Western priests answered: Yes, because in this religion, the one who is King is the person cherishing true love for his country's people. Therefore, it tells people of the nation to take these five guides to worship Kings and Lords" (Conference of Distinguished Teachers of Four Religions, 1996: 71). The conception of being loyal to the King is to be loyal to these five guides and rules. 
In 1630 some parishioners sent letters to the Pope (see: Nguyen, 2009 \& Nguyen, 2001) to express their belief in the religion and their admiration towards missionaries, which partly explained the reasons why the Court banned the religion. Firstly, the parishioners talked about how lucky it was for them to be able to learn about the religion: "The Lord of Heaven has sent the venerated teachers down to educate thousands of states and everywhere in the country An Nam ever; as they have not heard about the righteous religion before, (now) luckily they have heard about it" (Nguyen, 2001: 190). "I am fortunate to see that the two Fathers from Hoa Lang in the Western Region, who did not care about storms and dangers and followed God's command for the sake of the religion to teach the people, came to our lands for the sake of the religion to teach the people. Therefore, in our country, the number of followers is now more than 5,000 and the number of people wishing to learn the religion is increasing" (Nguyen, 2001: 190). The reason why the Court had a negative attitude towards Catholicism was the fact that the king and the mandarins did not understand about the religion: "Nevertheless, the nation's king and mandarins have not understood the religion, (resulting in) the never-ending insults" (Nguyen, 2001: 192).

All of the first kings of the Nguyen dynasty wanted to build a Confucian culture for the entire country. They considered Confucianism orthodox, the true "leader of all religions." Every other religion, such as Buddhism, Taoism, folk belief, and Christianity, were side religions and not legally supported. "In the third year of Gia Long (1804), the imperial order stated: Civilizing the people and creating positive customs are the first jobs of the reign. In the future, if the education is ruined, the policy will be weak, and there will be no positive customs in villages. As time goes by, it will get worse. Considering the activity of worshipping God and Buddha, there are many people who do not have religious rules; the village notables, as a result, will squeeze the people for their benefits, the poor and miserable must disperse. I now make a concession, amending the past things, making the rules for the villages, with the desire to get rid of all the bad things, and to follow the religion in all aspects. From now on, when it comes to worshipping Buddha, with temples and houses that are near collapsing, only reparation is allowed, while building new temples, casting bells, painting statues, building vegan-sacrifice esplanades, and hosting temple festivals are completely banned. Praying, doing penance, and solving the misfortune are useless" (Nguyen Dynasty's Cabinet, 1993: 376). Therefore, Catholicism was especially limited (Nguyen Dynasty's Cabinet, 1993: 377-378).

\section{Conclusion}

Conflicts regarding religion were raging in many aspects: habits and customs, beliefs, value system, ethics norms, ideology, political institution, etc. Although Catholicism has differences, even conflicts with Buddhism and Taoism in Vietnam, the deepest conflict was with Confucianism. Stress and fierceness were felt everywhere, in almost every region, especially the Middle of Vietnam. Tensions were felt on almost every level, among the people, local authorities, and central authorities. Most of the Confucian scholars and almost all feudal intellectuals showed hatred towards Catholicism and disobedience to the Court if it showed compliance towards Catholicism. Tran Trong Kim said: "First lunar month of 1874 , which was the $27^{\text {th }}$ year of Tu Duc's reign. In Nghe An, there were two baccalaureates called Tran Tan 陳玧 and Dang Nhu Mai 鄧如梅 who gathered all Confucian scholars in the county, then made a proclamation called "Demolish the Westerners; kill the heretics." The proclamation can be summarized as follows: "Although the Court is drawn by the Westerners, Confucian scholars still do not accept it. Therefore, first, please kill all parishioners, then demolish all Westerners to preserve our culture that has existed for more than 1000 years, etc. There were about three thousand non-governmental scholars (in Van Than) in total, and together they burnt and destroyed religious 
villages" (Tran, 1964: 520). Before, in 1861, based on Dang Duc Tuan's document, we can see that the Court was under severe pressure from multiple areas of the land. Lam Duy Hiep, the Director of the Bureau of Military of War (Thượng thư bộ Binh), said that King Tự Đức ("the superior") wanted to turn a blind eye but "had to suffer" the pressure from the memorial to the throne (tấu chương) of some mandarins and Confucian scholars:

"Thought superiors already ignored it

But in the provinces, reports keep coming

(and) ask for decisions

The superior also suffers from now on" (Vu-Nguyen, 2003: 220).

The trend was only getting worse, especially after the end of the colonial era. National independence and new ideology were the foundation to solve this conflict.

Misunderstanding and the lack of communication were also the reasons for the conflicts. Nguyen Hong Duong did not think highly of the knowledge about Catholicism that the kings and Confucian scholars during the Nguyen dynasty had. $\mathrm{He}$ wrote: "The way kings and lords acknowledge and criticize Catholicism that we quoted above is from the Confucian perspective. On the other hand, it can be said that kings and lords, even King Tu Duc, the king who had paid attention to researching Catholicism, had a poor and sometimes false knowledge about Catholicism. The monarch was already this way, the Confucian scholars' knowledge about Catholicism was even worse and more incorrect" (Nguyen, 2008: 200). The work The notes about Western Catholicism's secrets (Tây Dưong Gia Tô bi lucc) ${ }^{7}$ itself also expressed much significant incorrectness in the awareness of the Confucian scholars. Tran Van Toan opined that Catholicism understands the three religions more than the three religions understand Catholicism (Conference of Distinguished Teachers of Four Religions, 2002). In contrast, Catholicism itself has false assumptions about Confucianism specifically and about traditional Vietnamese ideologies and religions in general. This critical notion was expressed during the Conference of Distinguished Teachers of Four Religions. Catholic priest Giuse Phan Tan Thanh offered the following comment in this regard: "Religious opinions were narrated based on folk belief. The differentiation among Confucianism, Taoism, and Buddhism is sometimes unclear, let alone the differentiation among the schools within a given religion. However, we cannot ask for too much in a $19^{\text {th }}$-century agent's (thừa sai) knowledge about the history of different religions" (Phan, 2013)

The trend moved from Catholicism opposing Confucianism to Confucianism criticizing Catholicism. Catholicism, especially missionaries, looked down on East Asia's civilization, including Confucianism. It can be understood that Nguyễn Hồng Dương thought that Confucianism only (passively) fought against the attack from Catholicism (right from the beginning of Catholicism in Vietnam). He wrote: "When Confucianism wanted to protect their thought foundation, the Confucian scholars, whose representatives were the King and Confucian mandarins, naturally mounted a counter-attack on the Catholic thought. An academic fight thus formed in the field of thought" (Nguyen, 2008: 196). The above-mentioned debates in the field of ideology quickly turned to other forms of attacks of a fiercer nature, lasting throughout Vietnamese history. Even at the beginning of the twentieth century, when Confucianism as an institution was no longer there, the arguments and misunderstandings continued and have remained unresolved thereafter.

\footnotetext{
${ }^{7}$ The notes on Secrets of Western Catholicism (Tây Dưong Gia Tô bi lục) is a historical work in Chinese language. The authors of the book (Pham Ngo Hien, Nguyen Hoa Duong, Nguyen Ba Am and Tran Dinh Hien) were Jesuit missionaries who lived around the end of the 18th century, the beginning of the 19th century. The book is about negative things in Catholicism. However, according to some researchers, this is a fake work written by Confucians to attack Catholicism.
}

XLinguae, Volume 15 Issue 1, January 2022, ISSN 1337-8384, eISSN 2453-711X 


\section{Acknowledgments}

This research is funded by Vietnam National Foundation for Science and Technology

Development (NAFOSTED) under grant number 603.01-2020.01.

\section{Bibliographic references}

Baker, D. Y. (2013). "Finding God in the Classics: The Theistic Confucianism of Dasan Jeong” Dao, 12(1), 41-55. DOI 10.1007/s11712-012-9303-0.

Cao, H. T. (2003). Missionaries and the French colonial policy in Vietnam (18571914). Transl. Thuan Nguyen. Ho Chi Minh city: Religion.

Catechism. (1997). In Han-Nom language. In: The Catholic Church in Vietnam: Document for Internal Circulation Only. Ho Chi Minh city: Religion.

Conference of Distinguished Teachers of Four Religions. (1996). Documents for internal circulation only. Ho Chi Minh City: Religion.

Conference of Distinguished Teachers of Four Religions. (2002). Translated and revised by Tran Kim Vinh, Nguyen Huy Hung and Nguyen Duc Quy. In: La Vang book series/collection. San Francisco: The Federation of Vietnamese Catholics in The USA.

Dutton, E.G. (2017). A Vietnamese Moses - Philiphê Bỉnh and the Geographies of Early Modern Catholicism. Berkley: University of California.

Fernandes, G - Assuncao, C. (2017). "First Codification of Vietnamese by 17thcentury Missionaries: the Description of Tones and The influence of Portuguese on Vietnamese Orthography" Histoire Épistémologie Langage, 39(1), 155-176, DOI: 10.1051/hel/2017390108.

Gendreau, J. P. D. (2004). “Book on the comfort for the paralyzed” (冊安慰几劣) (Sách yên ủi kẻ liệt) in the Nom and National language. In: The Catholic Church in Vietnam: Document for Internal Circulation Only, Vol. 3. Ho Chi Minh city: Religion. Hoskins, A. J. (2014). "An Unjealous God? Christian Elements in a Vietnamese Syncretistic Religion” Current Anthropology, 55(10), 302-311.

Ly, M.T. (2010). The Four Books Commentary (Tứ thư bình giải). Ho Chi Minh city: Religion.

Maggs, W.B. 2000. "Science, Mathematics, and Reason: The Missionary Methods of the Jesuit Alexandre de Rhodes in Seventeenth-Century Vietnam" The Catholic Historical Review, 86 (3), 439-458.

Main Parts of Chronicles of The Great Nam. (1963)a. Vol.3, First part. Hanoi: Social Sciences.

Main Parts of Chronicles of The Great Nam. (1963)b. Vol.11. Hanoi: Social Sciences. Mcleod, W.M. (1991). The Vietnamese Response to French Intervention, 1862-1874. New York - London: Praeger.

Nguyen Dynasty's Bureau of National Historiography. (1998). Imperially Ordered Annotated Text Completely Reflecting the History of Viet, Vol. II. Hanoi: Education. Nguyen Dynasty's Cabinet. (1993). The Supreme Court Rule on Adoption. Vol. 11, Transl. Huy Giu Cao, Edit. Chuong Duy Le, Sieu Duc Dang, Doan Dai Phan. Ho Chi Minh City: Thuan Hoa.

Nguyen, H. (1959). History of Missions in Viet Nam, Vol. 1. Sai Gon: Contemporary (Hiện Tại).

Nguyen, H. (2009). History of Missions in Viet Nam, Vol. I (Jesuit Missionaries 1615-1663). Ho Chi Minh City: Encyclopedia.

Nguyen, H.D. (2008). "The relationship between Confucianism and Catholicism in Vietnam" in Annual report on Sino-Nom studies. Hanoi: Institute of Sino-Nom studies, 196-211.

Nguyen, H.L. (1992). Book of Changes - The Philosophy of Gentleman [Kinh Dịch Đạo của người quân tử]. Hanoi: Literature.

Nguyen, T. (1976). Collection of Poetry in the National Language, Thuat hung [述興]. Hanoi: Social Sciences. 
Nguyen, T.H. (2001). "On the two letters written in Chinese by some Tonkin parishioners to the Roman Pope in 1630" in Annual report on Sino-Nom studies. Hanoi: Institute of Sino-Nom studies, 187-195.

Nguyen, V. T. (2017). Life and Works of Dang Duc Tuan. Ho Chi Minh City: General.

Osborne, E. M. (1969). The French Presence in Cochinchina and Cambodia, Rule and Response (1859-1905). Transl. Ngo Bac. Ithaca and London: Cornell University Press. [Chapter 4: Education and National Language - The Development of a New Order, 89-108; Chapter 8: Education and National Language, A Qualified Triumph, 156-171]. Phan, B. C. (1990). Complete Works, Vol 6. Complied and Edited: Chương Thau. Thua Thien Hue: Thuan Hoa.

Phan. T.T.G. (2013). Conference of Distinguished Teachers of Four Religions. Vietnamese Dominicans Website. (cit. 23/11/2013). Available at: http://daminhvn.net/suy-tu-nghien-cuu/hoi-dong-tu-giao-8259.html.

Rhodes, D.A. (1993). Catechism divided into Eight Days. Ho Chi Minh city: Dai Ket Library.

Rhodes, D.A. (1994). History of the Kingdom of Tonkin. Ho Chi Minh city: Dai Ket Library.

Tran, Q.A. (2020). "From "Catechism divided into Eight Days" to "Conference of Distinguished Teachers of Four Religions"' [apologetic books in the Christian literature in Vietnam from 17th Century to 19th Century] Literature Studies, (7), 7184.

Tran, T.K. (1964). A brief History of Vietnam. 7th ed. Sai Gon: New Viet.

Truong, B.C. (1992). Tonkin Catholicism under the time of Bishop Pigneau (17711799). Ho Chi Minh City: Ho Chi Minh.

Tu, D. (1858). An Interpretation of the Way (In Vietnamese: Dao Bien), Literature collection of Tu Duc King. Hanoi: Historical Archives of the Institute of Philosophy.

$\mathrm{Vu}$, K. C. (2018). Ancestors - Cultural values, customs and habits of Vietnamese people in relation to mission. (30/11/2021) Available at: http://www.simonhoadalat.com/HOCHOI/TRIETHOC/ONGBA.htm

Vu, T. H - Nguyen, N. Q. (2003). "The Priest Dang Duc Tuan and his work A Narrative of Events in the Nam Country" in Annual report on Sino-Nom studies. Hanoi: Institute of Sino-Nom studies, 210-222.

Vuong, T.H. (2000). "One more Catholic stele written in Chinese characters" in Annual report on Sino-Nom studies. Hanoi: Institute of Sino-Nom studies, 194-198.

Words: 7232

Characters: 44447 (24,69 standard pages)

Assoc. prof. Dong Tai Nguyen, PhD.

Institute of Philosophy

Vietnam Academy of Social Sciences

59 Langha, Badinh, Hanoi

Vietnam

ntaidong@yahoo.com

XLinguae, Volume 15 Issue 1, January 2022, ISSN 1337-8384, eISSN 2453-711X 